\title{
Do doctors and patients agree on cardiovascular-risk management recommendations post-consultation? The INTERMEDE study
}

\author{
Anne-Cécile Schieber, Michelle Kelly-Irving, Christine Rolland, Anissa Afrite, \\ Chantal Cases, Paul Dourgnon, Pierre Lombrail, Jean Pascal and Thierry Lang
}

\section{ABSTRACT \\ Background}

Understanding interactions between patients and GPs may be important for optimising communication during consultations and improving health promotion, notably in the management of cardiovascular risk factors.

Aim

To explore the agreement between physicians and patients on the management of cardiovascular risk factors, and whether potential disagreement is linked to the patient's educational level.

\section{Design of study}

INTERMEDE is a cross-sectional study with data collection occurring at GPs' offices over a 2-week period in October 2007 in France.

\section{Method}

Data were collected from both patients and doctors respectively via pre- and post-consultation questionnaires that were 'mirrored', meaning that GPs and patients were presented with the same questions.

Results

The sample consisted of 585 eligible patients $(61 \%$ females) and $27 \mathrm{GPs}$. Agreement between patients and GPs was better for tangible aspects of the consultation, such as measuring blood pressure $(\kappa=0.84$, standard deviation $[S D]=0.04$ ), compared to abstract elements, like advising the patient on nutrition $(\kappa=0.36, \mathrm{SD}=0.04$ ), and on exercise $(\kappa=0.56, S D=0.04)$. Patients' age was closely related to level of education: half of those without any qualification were older than 65 years. The statistical association between education and agreement between physicians and patients disappeared after adjustment for age, but a trend remained.

\section{Conclusion}

This study reveals misunderstandings between patients and GPs on the content of the consultation, especially for health-promotion outcomes. Taking patients' social characteristics into account, notably age and educational level, could improve mutual understanding between patients and GPs, and therefore, the quality of care.

\section{Keywords}

cardiovascular diseases; communication; counselling; healthcare disparities; education; patients; physician-patient relations; physicians; socioeconomic factors.

\section{INTRODUCTION}

Understanding interactions between patients and GPs is potentially important for optimising communication during consultations and improving health promotion, notably in the management of cardiovascular risk factors. ${ }^{1-3}$ Little is known of the role played by these interactions in the maintenance or production of health disparities. ${ }^{4-6}$

The objective of this study was to explore the concordance between GPs and patients' declarations on the management of cardiovascular risk factors, and to explore whether potential disagreement was linked to patients' educational level.

\section{METHOD}

\section{Study design}

The design and methods of the INTERMEDE study's quantitative phase (Figure 1) have been described in detail elsewhere. ${ }^{7}$

Briefly, answers to questions on management of cardiovascular risk factors (obesity, arterial

A-C Schieber, MD; T Lang, MD, PhD; M Kelly-Irving, PhD; C Rolland, Université Toulouse III INSERM UMR 1027, Toulouse, France. A Afrite; C Cases, PhD; P Dourgnon, PhD; IRDES, Paris, France. P Lombrail, MD, PhD, Laboratoire de Santé Publique, CHU de Nantes, France. J Pascal, MD, PhD, Service d'Information Médicale, $\mathrm{CHU}$ de Nantes, France.

Address for correspondence

Dr Anne-Cécile Schieber, ONCOMIP, Inserm U558, 20-24 rue du pont Saint-Pierre, Toulouse, 31052, France. E-mail: annececile.schieber@gmail.com

Submitted: 8 April 2010; Editor's response: 22 April 2010; final acceptance: 19 July 2010.

OBritish Journal of General Practice

This is the full-length article (published online $28 \mathrm{Feb} 2011$ ) of an abridged version published in print. Cite this article as: Br J Gen Pract 2011; DOI: 10.3399/bjgp11X561159. 
hypertension, sedentary lifestyle, poor diet, alcohol and tobacco consumption) were collected from 'mirrored questionnaires', whereby patients and their GPs were asked the same questions respectively and independently after the consultation, in a sample of volunteer GPs and their patients (Appendix 1). Physicians were not advised to enquire about cardiovascular risk factors.

Educational level was used to measure socioeconomic status in three categories: A-level+ ( $\geq 12$ years' education); up to GCSE (general certificate of secondary education; 6-11 years' education); and no qualification ( $<6$ years' education).

\section{Statistical analysis}

Agreement between patients and GPs about what happened during consultations was analysed using the kappa statistic $\kappa .{ }^{8}$ The cluster effect of several patients sharing the same physician was taken into account by carrying out a multilevel logistic regression analysis, adjusting for age and sex. ${ }^{9}$ Analyses were conducted using Stata 10 statistical software.

\section{Ethics}

All data were anonymised, and the study received approval from the French Data Protection Authority (CNIL).

\section{RESULTS}

\section{Quantitative sample}

The sample consisted of 585 eligible patients and 27 GPs (Figure 2). Patient characteristics are described in Table 1. No difference was observed in educational level between the sexes; however, there was an association between age and education, where $48.7 \%$ of patients without any diploma were aged over 65 years. GP characteristics are described in Table 2.

\section{Agreement between physicians and patients}

Overall, concordance varied widely by topic (Appendix 2). Physician non-response to questions about the assessment of patients' physical activity level, and patients' cigarette and alcohol consumption were high $(18.7 \%, 14.4 \%$, and $39.7 \%$ respectively).

\section{Agreement between physicians and patients and patients' educational levels}

The bivariate analyses (Appendix 2) showed that as patients' level of education decreased, there was a significant decrease in agreement between patients and their GPs about information given by the GP during the consultation (blood pressure, glycaemia, weight). A similar gradient was observed for whether advice was given on nutrition, weight loss, and

\section{How this fits in}

Little is known about the role played by patient-physician interaction in

producing, maintaining, or reducing health disparities in the health services.

There is poor agreement between patients and GPs on advice given on diet and

exercise; while, in contrast, there is a good level of concordance on advice

given on alcohol and cigarette consumption. Comprehension between patients

and GPs may be influenced by patients' demographic characteristics, such as

age and educational level.

physical activity, with the poorest agreement for patients without any qualification. Among the discordant pairs, physicians were likely to declare having advised their patients on nutrition (67\%), when the patients claimed the opposite (33\%).

Associations with education level disappeared with the introduction of patients' age into the model (Table 3). No interaction term was statistically significant, and the multilevel analysis revealed no significant physician-level effect.

\section{DISCUSSION}

\section{Summary of main findings}

The research aim was to explore facets of the patient-physician interaction, which may generate quantitative data-collection procedure.
Figure 1. Diagram of

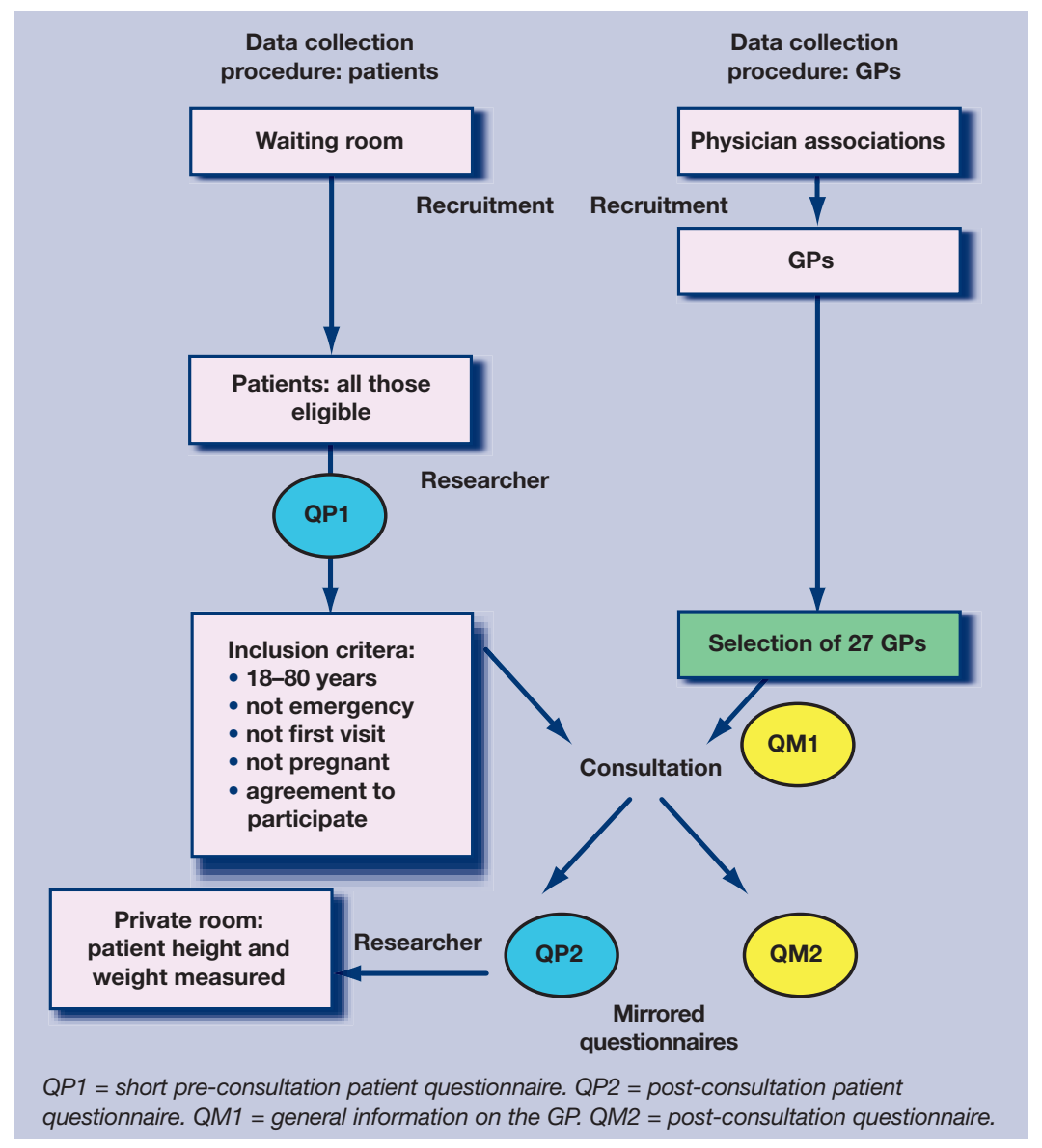


Figure 2. Diagram of quantitative patients' sample.

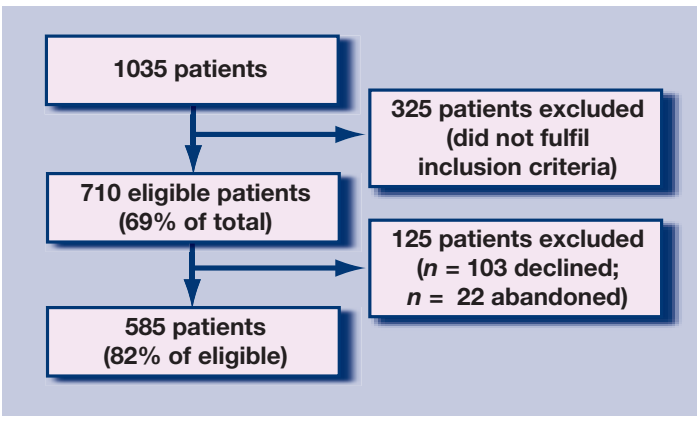

health disparities, notably concerning the management of cardiovascular risk factors in the context of primary care. The agreement between patients and their GPs was better for tangible aspects of the consultation, such as measurements and physical examinations undertaken (auscultation, measuring blood pressure and weight) and information given, compared to more abstract dimensions, such as counselling and assessing patients' physical activity and alcohol intake.

Discordances between patients and physicians were most salient for facets of the consultation relating to physical activity and nutrition, while, in contrast, there was a good level of concordance on whether advice was given on alcohol and cigarette consumption. Thus, the management of hypertension, and alcohol and cigarette consumption were discussed more readily and understood by both parties during a typical consultation, in contrast to issues of nutrition and

\section{Table 1. Patient characteristics.}

\begin{tabular}{lccc} 
Patient characteristics & Males, \% $(n)$ & Females, \% $(n)$ & $P$-value \\
\hline & $38.8(227)$ & $61.2(358)$ & \\
\hline Region & & & \\
Pays de la Loire & $38.2(66)$ & $61.9(107)$ & \\
Ile de France & $36.0(77)$ & $64.0(137)$ & \\
Midi-Pyrénées & $42.4(84)$ & $57.6(114)$ & NS \\
\hline Age, years & & & \\
18-34 & $24.8(56)$ & $22.9(82)$ & \\
$35-49$ & $22.6(51)$ & $31.0(111)$ & \\
$50-59$ & $27.0(61)$ & $16.2(58)$ & \\
$\geq 60$ & $25.7(58)$ & $29.9(107)$ & $<0.05$ \\
\hline Educational level, years of education & & & \\
A-level and higher ( $\geq 12$ years) & $43.0(92)$ & $47.6(165)$ & \\
Up to GCSE (6-11 years) & $39.3(84)$ & $30.3(105)$ & NS \\
No qualification (<6 years) & $17.8(38)$ & $22.2(77)$ & \\
\hline BMl, ${ }^{2}$ kg/m ${ }^{2}$ & & & \\
$<18.5$ & $0.9(2)$ & $3.7(13)$ & \\
$18.6-24.9$ & $41.2(93)$ & $50.6(176)$ & \\
$25.0-29.9$ & $42.0(95)$ & $26.4(92)$ & \\
$\geq 30.0$ & $15.9(36)$ & $19.3(67)$ & $<0.005$ \\
\hline
\end{tabular}

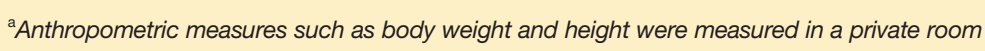
by the researcher; body mass index (BMI) was then computed as body weight divided by reported height squared $\left(\mathrm{kg} / \mathrm{m}^{2}\right)$. GCSE = general certificate of secondary education. $\mathrm{NS}=$ not significant. physical activity. This highlights that some facets of the management of cardiovascular risk factors appear to be dealt with more comfortably by both patients and GPs, whereas others are characterised by lack of clarity and misunderstanding.

Patients' age played a significant role in the concordance between physicians and patients, and was closely related to the level of education, with older patients having the lowest level of education. Although adjusting for age in the multivariate model deleted a statistical association between education and agreement/disagreement between patients and GPs, a trend across educational categories still remained. It is likely, therefore, that both age and educational level play a role in determining concordance between patients and GPs, whereby mutual comprehension may be affected when the patient is older and/or has a low education level. This could potentially lead to misunderstandings between patients and GPs and, consequently, to the quality of care being compromised.

\section{Strengths and limitations of the study}

To the authors' knowledge, this study is original in its design and contributes to understanding what goes on during a consultation between patients and GPs.

Potential bias and limitations of study design have been described and discussed in detail elsewhere. ${ }^{7}$ While $\kappa$ is the most commonly used statistic for measuring the agreement between two or more observers, the limitations of this statistic are well known, ${ }^{10}$ explaining why a multiple regression was carried out in the second step of the analyses.

\section{Comparison with existing literature}

This study brings to light misunderstandings between patients and GPs in the content of the consultation, especially with regard to prevention. A study of three general practices in England revealed how patients' and doctors' perceptions of the content of the consultation differed according to the patients' social class. ${ }^{11}$ Doctors perceived that they listened, examined, and gave advice less often to patients in the lowest social class compared to those in the upper social classes, and gave explanations more often to males than females. Taira et al showed that physicians were more likely to discuss diet and exercise with high-income patients than those from a low-income group; however, they were more likely to discuss smoking with low-income patients. ${ }^{12}$

A rich international literature highlights that a patient's inclination to participate in medical decision making, notably on cardiovascular disease management, varies by characteristics, such as age and education, but also by sex, coping style, and severity of condition. ${ }^{13-18}$ This emphasises the 
importance of a shared identity between patients and physicians that improves patients' trust, satisfaction, and observance, facilitating more positive healthcare interactions. ${ }^{19,20}$ Likewise, the way in which a physician perceives a patient (for example, intelligent, compliant) affects how they treat them during the consultation. ${ }^{21-25}$ If, as evidence suggests, the patient-physician relationship does affect a patient's healthcare trajectory, how they are treated, and their compliance with treatments could, in turn, lead to health disparities that will permeate across the healthcare system.

\section{Implications for clinical practice and future research}

Taking age and educational level into account during a consultation in general practice could improve the mutual comprehension between physicians and their
Table 2. GP characteristics.

\begin{tabular}{lcc} 
GP characteristics & Males & Females \\
\hline$n$ & 17 & 10 \\
\hline Age, years & 2 & 1 \\
$35-44$ & 7 & 5 \\
$45-54$ & 8 & 4 \\
$55-61$ & & \\
\hline Fees & 15 & 10 \\
Sector $1^{\text {a }}$ & 2 & 0 \\
Sector 2 & & \\
\hline Type of practice & & \\
Individual & 6 & 2 \\
Group of GPs & 9 & 5 \\
Multidisciplinary (GPs and specialists) & 2 & 3 \\
\hline
\end{tabular}

${ }^{a}$ standardised French National Health Service fee. ${ }^{\mathrm{b}}$ physician variable fee.

\section{Table 3. Agreement between physicians and patients on the management of cardiovascular risk factors during the consultation. Multilevel logistic regression analysis. ${ }^{\mathrm{a}}$}

\begin{tabular}{|c|c|c|c|c|c|c|}
\hline $\begin{array}{l}\text { Educational level, } \\
\text { years of education }\end{array}$ & OR (95\% Cl) & $\begin{array}{c}P- \\
\text { value }\end{array}$ & $\begin{array}{c}\text { OR adjusted for } \\
\text { patients' sex }(95 \% \mathrm{Cl})\end{array}$ & $\begin{array}{c}P- \\
\text { value }\end{array}$ & $\begin{array}{l}\text { OR adjusted for patients' } \\
\text { sex and age }(95 \% \mathrm{Cl})\end{array}$ & $\begin{array}{c}P- \\
\text { value }\end{array}$ \\
\hline \multicolumn{7}{|c|}{ Information given to the patient } \\
\hline \multicolumn{7}{|l|}{ High blood pressure } \\
\hline A-level and higher, $\geq 12$ & 2.9 (1.2 to 7.3$)$ & 0.023 & 2.9 (1.2 to 7.3$)$ & 0.021 & 1.6 (0.6 to 4.2$)$ & 0.383 \\
\hline Up to GCSE, $6-11$ & $1.7(0.7$ to 4.2$)$ & 0.221 & $1.8(0.7$ to 4.3$)$ & 0.194 & $1.1(0.4$ to 2.9$)$ & 0.821 \\
\hline No qualification, $<6$ & 1.0 & & 1.0 & & 1.0 & \\
\hline Log likelihood, -121.0 & -117.1 & & -116.8 & & -110.2 & \\
\hline \multicolumn{7}{|l|}{ Overweight } \\
\hline A-level and higher, $\geq 12$ & $2.8(1.4$ to 5.7$)$ & 0.005 & 2.8 (1.3 to 5.6$)$ & 0.006 & 1.9 (0.9 to 4.2$)$ & 0.094 \\
\hline Up to GCSE, $6-11$ & $1.5(0.8$ to 2.9$)$ & 0.253 & $1.4(0.7$ to 2.8$)$ & 0.319 & 1.1 (0.5 to 2.3$)$ & 0.798 \\
\hline No qualification, <6 & 1.0 & & 1.0 & & 1.0 & \\
\hline Log likelihood, -186.3 & -175.6 & & -174.5 & & -169.0 & \\
\hline \multicolumn{7}{|c|}{ Advice given to the patient } \\
\hline \multicolumn{7}{|l|}{ Weight loss } \\
\hline A-level and higher, $\geq 12$ & 2.4 (1.8 to 5.0$)$ & 0.016 & 2.4 (1.2 to 4.9$)$ & 0.017 & $1.9(0.9$ to 4.1$)$ & 0.121 \\
\hline Up to GCSE, 6-11 & $1.4(0.7$ to 2.8$)$ & 0.383 & $1.3(0.6$ to 2.7$)$ & 0.452 & $1.1(0.5$ to 2.2$)$ & 0.878 \\
\hline No qualification, $<6$ & 1.0 & & 1.0 & & 1.0 & \\
\hline Log likelihood, -193.7 & -182.9 & & -181.9 & & -179.8 & \\
\hline \multicolumn{7}{|l|}{ Nutrition } \\
\hline A-level and higher, $\geq 12$ & $2.6(1.4$ to 4.9$)$ & 0.002 & $2.6(1.4$ to 4.9$)$ & 0.002 & $1.8(0.9$ to 3.5$)$ & 0.097 \\
\hline Up to GCSE, 6-11 & $1.6(0.9$ to 3.0$)$ & 0.133 & $1.6(0.9$ to 3.1$)$ & 0.127 & $1.2(0.6$ to 2.3$)$ & 0.657 \\
\hline No qualification, $<6$ & 1.0 & & 1.0 & & 1.0 & \\
\hline Log likelihood, -241.7 & -227.76 & & -227.7 & & -221.8 & \\
\hline \multicolumn{7}{|l|}{ Exercise } \\
\hline A-level and higher, $\geq 12$ & 1.8 (1.0 to 3.3 ) & 0.051 & $1.6(0.9$ to 3.0$)$ & 0.1 & $1.1(0.6$ to 2.0$)$ & 0.837 \\
\hline Up to GCSE, $6-11$ & 2.1 (1.1 to 4.0$)$ & 0.025 & 2.3 (1.2 to 4.4$)$ & 0.012 & $1.6(0.8$ to 3.2$)$ & 0.155 \\
\hline No qualification, $<6$ & 1.0 & & 1.0 & & 1.0 & \\
\hline Log likelihood, -256.0 & -246.1 & & -245.9 & & -240.8 & \\
\hline \multicolumn{7}{|l|}{ Cigarette consumption } \\
\hline A-level and higher, $\geq 12$ & 0.7 (0.2 to 2.6$)$ & 0.564 & $0.7(0.2$ to 2.6$)$ & 0.567 & $1.2(0.3$ to 5.0$)$ & 0.802 \\
\hline Up to GCSE, $6-11$ & $0.2(0.1$ to 0.8$)$ & 0.031 & $0.3(0.1$ to 0.9$)$ & 0.038 & $0.4(0.1$ to 1.6$)$ & 0.197 \\
\hline No qualification, $<6$ & 1.0 & & 1.0 & & 1.0 & \\
\hline Log likelihood, -126.9 & -116.3 & & -113.1 & & -109.9 & \\
\hline
\end{tabular}

${ }^{a} A$ multivariate analysis was conducted for items statistically linked to the level of education $(\mathrm{P}<0.05)$. GCSE = general certificate of secondary education. $\mathrm{OR}=$ odds ratio. 
patients, and therefore the quality of care, notably in relation to management of cardiovascular risk factors. Future research on how best to advise patients on nutrition and exercise could be a first step.

\section{Funding body}

INSERM; research proposal 2005 IVRSP 'Inégalités sociales des santé'; project number A06024BS.

\section{Ethical approval}

The French National Commission for Information Technology and Civil Liberties. Patient physician interaction in general practice and health inequalities in a multidisciplinary study: design, methods and feasibility in the French INTERMEDE study. Volume $n^{\circ} 1228223$. Paris; 11 September 2007.

\section{Competing interests}

The authors have stated that there are none.

\section{Acknowledgements}

The INTERMEDE pilot study was funded by the Institut de Recherche en Santé Publique (IReSP) in 2005 and 2008. We would like to thank all the 27 GPs and 585 patients who generously agreed to participate in the different phases of the project. We would also like to thank the members of the fieldwork team who collected data on behalf of the study.

\section{Discuss this article}

Contribute and read comments about this article on the Discussion Forum: http://www.rcgp.org.uk/bjgp-discuss

\section{REFERENCES}

1. Kinnersley P, Stott N, Peters TJ, Harvey I. The patient-centredness of consultations and outcome in primary care. Br J Gen Pract 1999; 49(446): 711-716.

2. Scott A, Shiell, King M. Is general practitioner decision making associated with patient socio-economic status? Soc Sci Med 1996; 42(1): 35-46.

3. Haute Autorité de la Santé [French national authority for health]. Prise en charge des patients adultes atteints d'hypertension artérielle essentielle - actualisation 2005. http://www.has-

sante.fr/portail/upload/docs/application/pdf/HTA_2005_recos.pdf (accessed 12 Aug 2010).

4. Mackenbach JP, Stirbu I, Roskam AJ, et al, for the European Union Working Group on Socioeconomic Inequalities in Health. Socioeconomic inequalities in health in 22 European countries. $N$ Engl $J$ Med 2008; 358(23): 2468-2481.

5. Lombrail P. Inégalités de santé et d'accès secondaire aux soins. [Health care and secondary access to inequalities]. Rev Epidemiol Sante 2007; 55(1): 23-30.

6. Lang T. Ignoring social factors in clinical decision rules: a contribution to heath inequalities? Eur J Public Health 2005; 15(5): 441.

7. Kelly-Irving M, Rolland C, Afrite A, et al. Patient-physician interaction in general practice and health inequalities in a multidisciplinary study: design, methods and feasibility in the French INTERMEDE study. BMC Health Serv Res 2009; 9: 66.
8. Cohen J. A coefficient of agreement for nominal scales. Educ Psychol Meas 1960; 20: 37-46.

9. Merlo J, Chaix B, Ohlsson $\mathrm{H}$, et al. A brief conceptual tutorial of multilevel analysis in social epidemiology: using measures of clustering in multilevel logistic regression to investigate contextual phenomena. $J$ Epidemiol Community Health 2006; 60(4): 290-297.

10. Viera A, Garrett J. Understanding interobserver agreement: the kappa statistic. Fam Med 2005; 37(5): 360-363.

11. Martin E, Russel D, Goodwin S, et al. Why patients consult and what happen when they do. BMJ 1991; 303(6797): 289-292.

12. Taira DA, Safran DG, Seto TB, et al. The relationship between patient income and physician discussion of health risk factors. JAMA 1997; 278(17): 1412-1417.

13. Bensing JM, Tromp F, van Dulmen S, et al. Shifts in doctor-patient communication between 1986 and 2002: a study of videotaped general practice consultations with hypertension patients. BMC Fam Pract 2006; 7: 62.

14. Arber S, McKinlay J, Adams A, et al. Patient characteristics and inequalities in doctor's diagnostic and management strategies relating to CHD: a video-simulation experiment. Soc Sci Med 2006; 62(1): 103-115.

15. Arber S, McKinlay J, Adams A, et al. Influence of patient characteristics on doctors' questioning and lifestyle advice for coronary heart disease: a UK/US video experiment. Br J Gen Pract 2004; 54(506): 673-678.

16. Adams A, Buckingham CD, Lindenmeyer A, et al. The influence of patient and doctor gender on diagnosing coronary heart disease. Sociol Health Illn 2008; 30(1): 1-18.

17. Ribet C, Lang T, Zins M, et al. Do cardiovascular risk factors in men depend on their spouses' occupational category? Eur J Epidemiol 2001; 17(4): 347-56.

18. Scheitel SM, Boland BJ, Wollan PC, Silverstein MD. Patient-physician agreement about medical diagnoses and cardiovascular risk factors in the ambulatory general medical examination. Mayo Clin Proc 1996; 71(12): 1131-1137.

19. Street RL, Gordon H, Haidet P. Physicians' communication and perceptions of patients: is it how they look, how they talk, or is it just the doctor? Soc Sci Med 2007; 65(3): 586-598.

20. Street RL, O'Malley KJ, Cooper LA, Haidet P. Understanding concordance in patient-physician relationships: Personal and ethnic dimensions of shared identity. Ann Fam Med 2008; 6(3): 198-205.

21. Willems S, De Maesschalck S, Deveugele M, et al. Socio-economic status of the patient and doctor-patient communication: does it make a difference? Patient Educ Couns 2005; 56(2): 139-146.

22. Ong L, De Haes JC, Hoss AM, Lammes FB. Doctor-patient communication : a review of the literature. Soc Sci Med 1995; 40(7): 903-918.

23. Balsa AI, McGuire TG. Statistical discrimination in health care. J Health Econ 2001; 20(6): 881-907.

24. Balsa AI, McGuire TG. Prejudice, clinical uncertainty and stereotyping as sources of health disparities. J Health Econ 2003; 22(1): 89-116.

25. Lynch JW, Kaplan GA, Salonen JT. Why do poor people behave poorly? Variation in adult health behaviours and psychosocial characteristics by stages of the socioeconomic lifecourse. Soc Sci Med 1997; 44(6): 809-819. 
Appendix 1. Items explored through mirrored questionnaires.

\begin{tabular}{|c|c|c|}
\hline Item & Patient questionnaire & GP questionnaire \\
\hline $\begin{array}{l}\text { Blood pressure measured } \\
\text { during consultation }\end{array}$ & $\begin{array}{l}\text { During this consultation, did the GP } \\
\text { measure your blood pressure? }\end{array}$ & $\begin{array}{l}\text { During this consultation, did you } \\
\text { measure the patient's blood pressure? }\end{array}$ \\
\hline $\begin{array}{l}\text { Auscultation undertaken } \\
\text { during consultation }\end{array}$ & $\begin{array}{l}\text { During this consultation, did your GP } \\
\text { listen to your heart or lungs } \\
\text { (with a stethoscope)? }\end{array}$ & $\begin{array}{l}\text { During this consultation, did you } \\
\text { auscultate your patient? }\end{array}$ \\
\hline $\begin{array}{l}\text { Weight measured during } \\
\text { consultation }\end{array}$ & $\begin{array}{l}\text { During this consultation, did the GP } \\
\text { measure your weight? }\end{array}$ & $\begin{array}{l}\text { During this consultation, did you measure } \\
\text { the patient's weight? }\end{array}$ \\
\hline $\begin{array}{l}\text { High blood pressure: } \\
\text { information given to the } \\
\text { patient }\end{array}$ & $\begin{array}{l}\text { During this consultation, did the GP } \\
\text { tell you that your blood pressure } \\
\text { was high? }\end{array}$ & $\begin{array}{l}\text { During this consultation, did you tell your } \\
\text { your patient that the blood pressure was } \\
\text { high? }\end{array}$ \\
\hline $\begin{array}{l}\text { Hypercholesterolaemia: } \\
\text { information given to the patient }\end{array}$ & $\begin{array}{l}\text { During this consultation, did the GP tell } \\
\text { you that your cholesterol level was high? }\end{array}$ & $\begin{array}{l}\text { During this consultation, did you tell your } \\
\text { patient that the cholesterol level was high? }\end{array}$ \\
\hline $\begin{array}{l}\text { Hyperglycaemia: information } \\
\text { given to the patient }\end{array}$ & $\begin{array}{l}\text { During this consultation, did the GP tell } \\
\text { you that your glucose level was high? }\end{array}$ & $\begin{array}{l}\text { During this consultation, did you tell your } \\
\text { patient that the glucose level was high? }\end{array}$ \\
\hline $\begin{array}{l}\text { Overweight: information given } \\
\text { to the patient }\end{array}$ & $\begin{array}{l}\text { During this consultation, did the GP tell } \\
\text { you that your weight was high? }\end{array}$ & $\begin{array}{l}\text { During this consultation, did you tell your } \\
\text { patient that the weight was high? }\end{array}$ \\
\hline Advice on exercise given & $\begin{array}{l}\text { During this consultation, did the GP advise } \\
\text { you to do more physical activity? }\end{array}$ & $\begin{array}{l}\text { During this consultation, did you advise } \\
\text { your patient to do more physical activity? }\end{array}$ \\
\hline Advice on weight loss given & $\begin{array}{l}\text { During this consultation, did the GP advise } \\
\text { you to lose weight? }\end{array}$ & $\begin{array}{l}\text { During this consultation, did you advise } \\
\text { your patient to lose weight? }\end{array}$ \\
\hline $\begin{array}{l}\text { Advice on cigarette } \\
\text { consumption given }\end{array}$ & $\begin{array}{l}\text { During this consultation, did the GP advise } \\
\text { you to reduce or to stop smoking? }\end{array}$ & $\begin{array}{l}\text { During this consultation, did you advise } \\
\text { your patient to reduce or to stop smoking? }\end{array}$ \\
\hline $\begin{array}{l}\text { Advice on alcohol } \\
\text { consumption given }\end{array}$ & $\begin{array}{l}\text { During this consultation, did the GP advise } \\
\text { you to reduce or to stop your alcohol } \\
\text { consumption? }\end{array}$ & $\begin{array}{l}\text { During this consultation, did you advise } \\
\text { your patient to reduce or to stop your } \\
\text { alcohol consumption? }\end{array}$ \\
\hline Advice on nutrition & $\begin{array}{l}\text { During this consultation, did the GP give } \\
\text { you advice on nutrition? }\end{array}$ & $\begin{array}{l}\text { During this consultation, did you give your } \\
\text { patient advice on nutrition? }\end{array}$ \\
\hline Physical activity level assessed & $\begin{array}{l}\text { Do you usually take part in sport or physical } \\
\text { activity, such as gardening or walking? }\end{array}$ & $\begin{array}{l}\text { Does your patient usually take part in } \\
\text { sport or physical activity, such as } \\
\text { gardening or walking? }\end{array}$ \\
\hline $\begin{array}{l}\text { Cigarette consumption } \\
\text { assessed }^{\text {a }}\end{array}$ & Do you smoke? & Does your patient smoke? \\
\hline $\begin{array}{l}\text { Alcohol consumption } \\
\text { assessed }^{\mathrm{a}}\end{array}$ & $\begin{array}{l}\text { How many standards glasses of alcohol } \\
\text { do you usually drink per day? }\end{array}$ & $\begin{array}{l}\text { How many standards glasses of alcohol } \\
\text { does your patient usually drink per day? }\end{array}$ \\
\hline
\end{tabular}

${ }^{a}$ Answers to questions on cigarette and alcohol consumption were provided in two categories: respectively, regular and occasional smokers versus non-smokers; $\leq 2$ standard glasses of alcohol per day versus $>3$ glasses per day. 


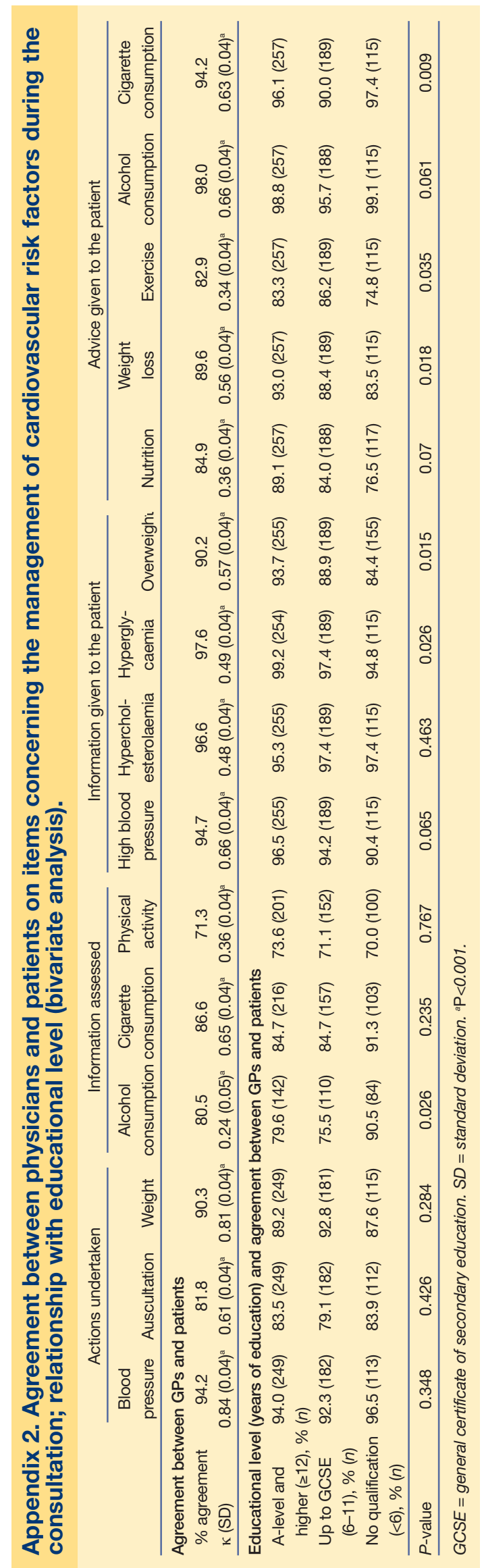

